\title{
Assessment of the Knowledge and Self-Medication Behaviours towards Antibiotics among Nursing Students at King Saud Bin Abdulaziz University for Health Sciences, Al Ahsa
}

\author{
Perwez Khanam* and Dana Haj-Ali
}

King Saudbin Abdulaziz University for Health Sciences, Al Ahsa, KSA

"Corresponding author: Perwez Khanam, King Saudbin Abdulaziz University for Health Sciences- Al Ahsa, KSA, Tel: 00966502833958; E-mail: tanyaata@yahoo.com

Received date: September 19, 2017; Accepted date: October 23, 2017; Published date: October 31, 2017

Copyright: ( 2017 Khanam P, et al. This is an open-access article distributed under the terms of the Creative Commons Attribution License, which permits unrestricted use, distribution, and reproduction in any medium, provided the original author and source are credited

\section{Abstract}

Background: Self-medication with antibiotics is a common phenomenon, especially in the developing world where infectious diseases are common causes of death and a major cause of resistance towards antibiotics. Nursing students are susceptible to self-medication on the account of handling and having access to different types of antibiotics in their future practices.

Objective: The aim of this study is to estimate the knowledge of antibiotics and prevalence of self-medication with antibiotics among third year nursing students of King Saud Bin Abdul Aziz University for health sciences, Al Ahsa, Saudi Arabia.

Methods: A questionnaire comprising of twenty five questions on the self-medication behaviors and the knowledge of antibiotics was distributed to a sample of 80 students. Data were statistically analyzed using SPSS version 21. Descriptive statistics including frequencies, percentages, means and standard deviations were computed. A P value of $<0.05$ was considered as statistically significant.

Results: Results indicate that among the participants $35.44 \%$ practiced self-medication using antibiotics. The most commonly used antibiotics were amoxicillin $(68 \%)$, followed by erythromycin $(28 \%)$. Regarding the source of antibiotics used, most students obtained their antibiotics from community pharmacies $(60.7 \%)$, whereas $21.4 \%$ of them used leftover antibiotics from family and friends. Antibiotics were most commonly used for treatment of cold-flu, sore throat and fever $(70.3 \%)$. The majority of students checked the instructions of use $(93 \%)$.In terms of knowledge of antibiotics uses $82.3 \%$ of students were aware that antibiotics act on bacteria; however, more than $50 \%$ of them were not familiar with the term, antibiotic 'resistance'.

Conclusion: The findings from this study highlight the prevalence of self-medication and usage of antibiotics among nursing students, the lack of some important knowledge and the risks associated with them.

Keywords: Self-medication; Antibiotic; Nursing student

\section{Introduction}

Antibiotics are drug that work by either killing or slowing the growth of bacteria and so are used to treat bacterial infections. They are chemicals produced by microorganisms in nature by soil bacteria and fungi. Nowadays, antibiotics available in the market are either produced by microbial fermentation or are derived via semi-synthetic route using the existing antibiotic backbone structure.

Resistant to major antibiotic drugs is emerging as a major global public health problem. The most important cause of this resistance is irrational use of antibiotic by self-medication. Self-medication is defined as a human behavior in which an individual uses unprescribed drugs to treat untreated and often undiagnosed medical ailments. Selfmedication with antibiotic is a common phenomenon, especially in the developing world where infectious diseases are common causes of death [1].
The practice of self-medication is leading to inappropriate use of antibiotics for the treatment of patients with common infections which subsequently have implications for increasing treatment costs and adverse events [2]. Self-medication with antibiotics is a common practice in most countries including Saudi Arabia where drug regulation is not strict and is one of the reasons for the increase in the antibiotic resistance of the microorganisms in these areas. According to one surveillance conducted in Spain the researchers have found that $30 \%$ of the antibiotics consumed by the population have not been prescribed by physicians [3]. A high prevalence of self-medication with antibiotics has also been repeatedly found in Southern and Eastern European countries and Sudan resulting in high levels of antibiotic resistance [4,5]. In a study conducted in Pakistan, the researchers have found the prevalence of self-medication with antibiotics among the non-medical university students to be as high as 50\% [6]. Several studies in the USA have also shown considerable self-medication with antibiotics obtained from leftovers from previous courses, at a local pharmacy or from outside the country [7-10]. 
Page 2 of 6

Dispensing of antibiotic without a medical prescription has been illegal for pharmacists in Saudi Arabia for more than three decades [11]. However, studies show a high rate of antibiotic sales without prescription for different infections due to lack of adherence to these regulations [12-14].

Self-medication with unprescribed antibiotics not only includes acquiring antibiotics without a prescription (OTC) but also by sharing antibiotics with relatives or friends or using left-over antibiotics stored at residential place. Self-medication with antibiotic is a serious global health problem [15]. Resistant bacteria do not respond to the antibiotics and continue to cause infection. Some infections are difficult to cure even with new or experimental drugs. Producing new antibiotics is an expensive and challenging task. Proper knowledge of antibiotic, the dose of administration and their side effects is necessary for its appropriate use. Nursing students are susceptible to selfmedication on account of handling and having access to different types of antibiotics in their future practices. Various studies on nurses suggest that a sizeable population of them experience self -medication with antibiotics $[16,17]$.

Studies on knowledge and self-medication behavior of nursing students towards antibiotics are necessary to help with the planning of interventions to improve the use of medicines in the country. The nursing students are the future practicing nurses and their behavior will largely influence the behavior of society. In this study we estimate the knowledge of the antibiotic and prevalence of self-medication with antibiotics among third year nursing students of the King Saud Bin Abdul Aziz University for health sciences, Al Ahsa, Saudi Arabia.

\section{Materials and Methods}

The King Saud bin Abdulaziz University administration and the research committee approved and had given the permission to pursue this study. This was a nursing college based cross sectional descriptive study. All the third year nursing students of King Saud bin Abdulaziz University for health sciences were the study population. A pilot study was conducted on five nursing students before the start of this study. These five nursing students were later excluded from the study. A written consent was taken from each participant. Open ended and close ended questionnaires were used to collect the responses. The validity and reliability were checked based on pilot study. The questionnaire was revised accordingly. The questionnaires comprised of fifteen questions on the self-medication behaviors and 10 questions on the knowledge of antibiotics. The questionnaires on self-medication behaviors consisted of indication of using the antibiotic, the source of antibiotic acquirement, antibiotic dose and any experience of their side effects. The questionnaires on knowledge of antibiotic consisted of definition of antibiotic, indication of antibiotics and various questions on knowledge of antibiotic resistance. The correct responses of each question were determined by the study investigator who is herself the Lecturer of pharmaceutical science. The questionnaires were distributed to the students in the leisure period and collected immediately after completion. Demographic information of the participants regarding the age, sex and residence status was also recorded. The data were entered into the personal computer using SPSS version 21. Descriptive statistics including frequencies, percentages, means and standard deviations were computed. The Fisher's Exact Chi-square $\left(\chi^{2}\right)$ test was used in determining statistically significant. A P value of $<0.05$ was considered as statistically significant.

\section{Results}

A total of 79 nursing students (total population of third year students) were distributed the questionnaires with a mean age of 20.85 (SD +/- 0.935) with a range of 19-25 Years. More than fifty percent $(\mathrm{N}=42,53.2 \%)$ of them were from the rural area while thirty seven $(46.8 \%)$ of them belonged to urban area (Table 1$)$.

\begin{tabular}{|l|l|}
\hline Variable & No (\%) \\
\hline Number of students & $79(100)$ \\
\hline Gender & All female students \\
\hline Age & Mean: 20.85 years \\
\hline & Range: $19-25$ years \\
\hline & Std. deviation: 0.935 \\
\hline Geographical distribution & Rural: 42 (53.2) \\
\hline & Urban: $37(46.8)$ \\
\hline
\end{tabular}

Table 1: Demographic characteristics.

\section{Self-medication behavior}

More than thirty five percent of the students $(\mathrm{N}=28)$ asserted that they are involved in self-medication behavior. Sixty eight percent $(\mathrm{N}=19)$, of them took amoxicillin as self-medication while more than twenty eight percent $(\mathrm{N}=8)$ and $3.5 \%(\mathrm{~N}=1)$ took erythromycin and metronidazole respectively. The pharmacy counter $(\mathrm{N}=17,60.7 \%)$ was the most preferred source of acquiring the antibiotic for selfmedication followed by left over antibiotics from friends or family members $(\mathrm{N}=6,21.4 \%)$, respectively. As far as the indication of antibiotic use is concerned more than seventy percent $(\mathrm{N}=19,70.3 \%)$ used these antibiotics for cold-flu, sore throat and fever while almost twenty six percent $(\mathrm{N}=7,25.9 \%)$ of them also used it for skin wounds and two students $(3.8 \%)$ used it for diarrhea. When asked about the checking of instruction before the use of the antibiotic, more than forty six percent $(\mathrm{N}=13,46.4 \%)$ agreed that they always checked the instructions of use inside the leaflets and equal number of students asserted that they sometimes checked the instruction while only seven percent agreed that they never read the instruction. Data concerning the dose of antibiotic for self-medication revealed that more than twenty one students $(\mathrm{N}=6)$ used the dose by checking the package insert while twenty five percent $(\mathrm{N}=7)$ of them used the dose by consulting the doctors and family members. Only ten percent of the student $(\mathrm{N}=3)$ used internet to find out the dose of antibiotic for selfadministration.

The geographical location $(\mathrm{P}=0.427)$ and age was not statistically significant with the prevalence of self-medication behavior towards antibiotic. The details of self-medication behavior are shown in Table 2 . 
Citation: Khanam P, Haj-Ali D (2017) Assessment of the Knowledge and Self-Medication Behaviours towards Antibiotics among Nursing Students at King Saud Bin Abdulaziz University for Health Sciences, Al Ahsa. J Nurs Care 6: 431. doi:10.4172/2167-1168.1000431

Page 3 of 6

\begin{tabular}{|c|c|c|}
\hline Variables & No. $(\%)$ & \\
\hline \multicolumn{3}{|l|}{ Self-medication } \\
\hline Yes & $28(35.44)$ & \\
\hline No & $51(64.56)$ & \\
\hline Self-medication prevalence & & $P=0.427$ \\
\hline Rural student & $14(50.0)$ & \\
\hline Urban student & $14(50.0)$ & \\
\hline \multicolumn{3}{|l|}{ Antibiotic taken as self-medication } \\
\hline Amoxicillin & $19(67.85)$ & \\
\hline Erythromycin & $8(28.58)$ & \\
\hline Metronidazole & $1(3.57)$ & \\
\hline \multicolumn{3}{|l|}{ Source of procurement of antibiotic } \\
\hline Community pharmacy counter & $17(60.7)$ & \\
\hline $\begin{array}{l}\text { Left over antibiotics from friends or family } \\
\text { members }\end{array}$ & $6(21.4)$ & \\
\hline Left over antibiotic from previous prescription & $5(17.9)$ & \\
\hline \multicolumn{3}{|l|}{$\begin{array}{l}\text { Medical conditions for which the antibiotic } \\
\text { was used }\end{array}$} \\
\hline Cold, flu, sore throat and fever & $19(70.3)$ & \\
\hline Skin wounds & $7(25.9)$ & \\
\hline Diarrhea & $2(3.8)$ & \\
\hline \multicolumn{3}{|l|}{$\begin{array}{l}\text { Checking the instruction of use inside the } \\
\text { leaflets before use (Response of the student) }\end{array}$} \\
\hline Yes always & $13(46.4)$ & \\
\hline Yes sometimes & $13(46.4)$ & \\
\hline Never & $2(7.2)$ & \\
\hline \multicolumn{3}{|l|}{$\begin{array}{l}\text { Checking the expiry date of the antibiotic } \\
\text { before use }\end{array}$} \\
\hline Yes & $20(71.4)$ & \\
\hline No & $8(28.6)$ & \\
\hline \multicolumn{3}{|l|}{$\begin{array}{l}\text { Decision on the dose of antibiotic for self- } \\
\text { medication }\end{array}$} \\
\hline By checking the package insert & $6(21.4)$ & \\
\hline By consulting a doctor & $7(25.0)$ & \\
\hline By consulting a pharmacist & $5(17.9)$ & \\
\hline From the internet & $3(10.7)$ & \\
\hline By consulting family members & $7(25.0)$ & \\
\hline \multicolumn{3}{|l|}{$\begin{array}{l}\text { Have you ever changed the dose of antibiotic } \\
\text { during the course of self-treatment? }\end{array}$} \\
\hline Yes sometimes & $9(32.1)$ & \\
\hline
\end{tabular}

\begin{tabular}{|c|c|}
\hline Never & $19(67.9)$ \\
\hline \multicolumn{2}{|l|}{$\begin{array}{l}\text { Did you ever experience any side effect when } \\
\text { treating yourself with antibiotics? }\end{array}$} \\
\hline Yes & $2(7.1)$ \\
\hline No & $26(92.9)$ \\
\hline \multicolumn{2}{|l|}{$\begin{array}{l}\text { How did you react when you experienced } \\
\text { such side effects? }\end{array}$} \\
\hline Stopped taking antibiotics & $14(50.0)$ \\
\hline Consulted a doctor & $14(50.0)$ \\
\hline \multicolumn{2}{|l|}{$\begin{array}{l}\text { Were you satisfied with the results of self- } \\
\text { medication using antibiotics? }\end{array}$} \\
\hline Yes & 24 (89.9) \\
\hline No & $4(11.1)$ \\
\hline
\end{tabular}

Table 2: Details of self- medication behaviour.

\section{Knowledge of Antibiotics}

More than eighty percent of the students $(\mathrm{N}=65,82.3 \%)$ were affirmative in saying that antibiotics treat infections caused by bacteria. When asked about antibiotic resistance, more than fifty percent students $(\mathrm{N}=42,53.2 \%)$ did not have any idea about it. Among the students who knew about the antibiotic resistance, nearly seventy one percent $(\mathrm{N}=30)$ of them agreed that antibiotic resistance occurs when body becomes resistant to antibiotics and they no longer work and almost $67 \%(\mathrm{~N}=28)$ of them agreed that in case of bacterial resistant the treatment of infection is very difficult or impossible. Sixty four percent $(\mathrm{N}=27)$ of the students who knew about the antibiotic resistance also agreed that self- medication using antibiotics can contribute to development of antibiotic resistance while 57\% percent $(\mathrm{N}=24)$ of them agreed that bacteria which are resistant to antibiotics can spread from person to person. Almost eighty three percent $(\mathrm{N}=35)$ did not know that antibiotic resistance is a global health concern (Table 3 and Figures 1-4).

\begin{tabular}{|l|l|}
\hline Variables & No. (\%) \\
\hline Antibiotics treat infections caused by & $65(82.3)$ \\
\hline Bacteria & $1(1.3)$ \\
\hline Fungi & $13(16.4)$ \\
\hline Virus & \\
\hline Are you familiar with the term "Antibiotic Resistance'? & $37(46.84)$ \\
\hline Yes & $42(53.16)$ \\
\hline No & $12(28.58)$ \\
\hline $\begin{array}{l}\text { Antibiotic resistance occurs when your body becomes } \\
\text { resistant to antibiotics and they no longer work }\end{array}$ & $30(71.42)$ \\
\hline True & \\
\hline False & $\begin{array}{l}\text { If bacteria are resistant to antibiotic ,it can be very difficult } \\
\text { or impossible to treat the infections they cause }\end{array}$ \\
\hline
\end{tabular}


Citation: Khanam P, Haj-Ali D (2017) Assessment of the Knowledge and Self-Medication Behaviours towards Antibiotics among Nursing Students at King Saud Bin Abdulaziz University for Health Sciences, Al Ahsa. J Nurs Care 6: 431. doi:10.4172/2167-1168.1000431

Page 4 of 6

\begin{tabular}{|l|l|}
\hline True & $28(66.66)$ \\
\hline False & $14(33.34)$ \\
\hline $\begin{array}{l}\text { Antibiotic resistance is an issue in other countries but not } \\
\text { here }\end{array}$ & \\
\hline True & $7(16.66)$ \\
\hline False & $35(83.34)$ \\
\hline $\begin{array}{l}\text { Antibiotic resistance is only a problem for people who take } \\
\text { antibiotics regularly }\end{array}$ & \\
\hline True & $20(47.61)$ \\
\hline False & $22(52.39)$ \\
\hline $\begin{array}{l}\text { Bacteria which are resistant to antibiotics can spread from } \\
\text { person to person }\end{array}$ & \\
\hline True & $24(57.14)$ \\
\hline False & $18(42.86)$ \\
\hline $\begin{array}{l}\text { Antibiotic-resistant infections could make medical } \\
\text { procedures like surgery, organ transplants and cancer } \\
\text { treatment much more dangerous }\end{array}$ & \\
\hline True & $27(64.28)$ \\
\hline False & $13(30.96)$ \\
\hline $\begin{array}{l}\text { Self-medication using antibiotics can contribute to } \\
\text { development of antibiotic resistance }\end{array}$ & $29(69.04)$ \\
\hline True & $15(35.72)$ \\
\hline False & \\
\hline & \\
\hline
\end{tabular}

Table 3: Knowledge of antibiotics.

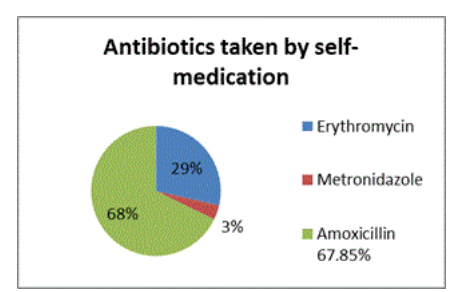

Figure 1: Antibiotics taken by self-medication.

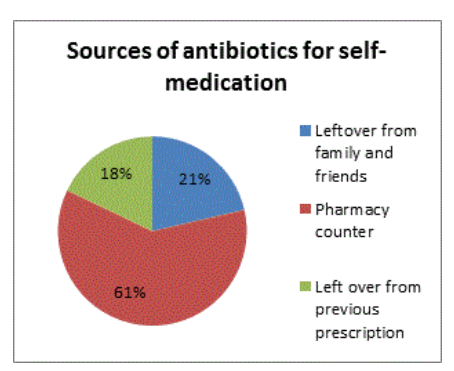

Figure 2: Sources of antibiotics for self-medication.

\section{Discussion}

To the best of our knowledge, this was the first study done to assess the knowledge and self-medication behaviors with antibiotics among nursing students in Saudi Arabia. Our study showed that the prevalence of self-medication was $35 \%$ among the third year nursing students of king Saud bin Abdulaziz University for health sciences. However it is not as frequent as found in a similar study conducted in India (87.50\%) [16], India (65.1) [18], Pakistan (53\%) [6], Australia (91.7\%) [19] and Brazil (38.8\%) [20]. But it is higher than that observed among nursing workers of private hospitals of Brazil (28.2\%) [21]. Though we could not find the prevalence of self-medication on the nursing students in Saudi Arabia, but in one population study done on college students, the prevalence of self-medication ranged between $77-80 \%$ [22]. The present self-medication among the nursing students is expected to increase once they come in practice.

Amoxicillin was the most frequently used antibiotic followed by erythromycin and metronidazole. Amoxicillin has also been used most frequently as self-medication in other study conducted in Ghana [23] and Pakistan [6]. Similar observations were reported in studies conducted exclusively on self-medication with antibiotics in Nigeria [24], Zaria and Greece [25]. Beta-lactams were most commonly used for self-medication. The self-medication with beta lactam without proper dose and duration of use can lead to drug resistance which is really a great threat to the health of the human being.

Community pharmacy counter was the most common source for procurement of antibiotic in our study in spite of the fact that antibiotic is legally a prescribed medicine. A study conducted in 
central area of Saudi Arabia has shown that among the fifty percent over the counter dispensed medicine; twenty percent of them were antibiotics [26]. In a similar study in India, almost 27 percent of the nursing students used on counter antibiotic as self-medication [27].

In the present study the most common symptoms leading to antibiotic self-medication were cold, flu, sore throat and fever $(70.3 \%)$ followed by skin wounds (25.9\%). The student nurses were found to be involved in antibiotic self-medication most frequently for the common symptoms of fever, sore throat and runny nose in similar studies in Pakistan and India [28,29].

As compared to other studies, the knowledge about antibiotic of nursing students was excellent. However, our study showed that knowledge of antibiotic resistance and implications of self-medication is inadequate. The same type of findings has been reported in other studies in Jordan [30] and USA [31]. Inadequate knowledge of antibiotic resistance and its implications may result in serious outcomes.

\section{Limitations in This Study}

Since the study was done on a small sample which consisted of the third year female students of a female nursing college of a specific region, results cannot be generalized. The main limitation of this study is that the data collected were self-reported which may introduce some bias in the behavioral pattern of the respondents. The reported data may represent an underestimation of the problem as students may choose not to reveal such data.

\section{Conclusion}

This study has shown that self-medication with antibiotics though not very common but there is a potential to become common once these third year complete their studies and go in practice. The knowledge of pharmacology taught in third year probably has led to a false sense of confidence in self-diagnosis and self-management leading them to self-prescribe irrationally. Drug-related knowledge gained during this period and easy access might have encouraged their self-medication habit. There is a need for a review of educational programs especially the teaching of clinical pharmacology to include topics on self- medication and judicious use of medicines. At the policy-making level, there is an urgent need to legislate and implement laws restricting access to antibiotics in Saudi Arabia. Further educational interventions are necessary to improve students' understanding on antibiotic resistance, and to correct some wrong behaviors related to antibiotic use. It should be emphasized that antibiotics be used only on medical prescription, for a defined period of time to treat specific medical conditions (for e.g. cold and flu should not be treated with antibiotics).

\section{References}

1. Eystathios S, Panagiotis M, Athanasia P, Aristofanis G, George M, et al. (2010) Self-medication with antibiotics in rural population in Greece: A cross-sectional multicenter study. BMC Fam Pract 11: 58.

2. Arch GM, Vanessa, Mark C (2008) Factors affecting latino adults' use of antibiotics for self-medication. J Am Board Fam Med 21: 128-134.

3. Campos J, Ferech M, Lázaro E (2007) Surveillance of outpatient antibiotic consumption in Spain according to sales data and reimbursement data. J Antimicrob Chemother 60: 698-701.
4. Grigoryan L, Monnet DL, Haaijer-R FM, Bonten MJ, Lundborg S, et al. (2010) Self-medication with antibiotics in Europe: A case for action. Curr Drug Saf 5: 329-332.

5. Sudan Abdel MA, Idris E, Lloyd M, Lukman T (2005) Self-medication with Antibiotics and Antimalarial in the community of Khartoum state, Sudan. J Pharm Pharm Sci 8: 326-331.

6. Syed JS, Hamna A, Rija BR, Sidra N, Mirrah M, et al. (2014) Selfmedication with antibiotics among non-medical university students of Karachi: A cross-sectional study. BMC Pharmacol Toxicol 15: 74.

7. Mainous AG, Cheng AY, Garr RC (2005) Non-prescribed antimicrobial drugs in Latino community, South Carolina. Emerg Infect Dis 11: 883-888.

8. Richman PB, Garra G, Eskin B (2001) Oral antibiotic use without consulting a physician: a survey of ED patients. Am J Emerg Med 19: 57-60.

9. McKee MD, Mills L, Mainous AG (1999) Antibiotic use for the treatment of upper respiratory infections in a diverse community. J Fam Pract 48: 993-996.

10. Vanden Eng J, Marcus R, Hadler JL (2003) Consumer attitudes and use of antibiotics. Emerg Infect Dis 9: 1128-1135.

11. Bawazir SA (1992) Prescribing pattern at community pharmacies in Saudi Arabia. Int Pharm J 6: 222-224.

12. Al-Ghamdi M (2001) Empirical treatment of uncomplicated urinary tract infection by community pharmacist in the Eastern province of Saudi Arabia. Saudi Med J 22: 1105-1108.

13. Al-Freihi H, Ballal SG, Jaccarini A, Young M S, Abdul-Cader Z, et al. (1987) Potential for drug misuse in the eastern province of Saudi Arabia. Anal Saudi Med 7: 301-305.

14. Alkhawajah AM, Eferakeya AE (1992) The role of pharmacists in patients' education on medication. Public Health 106: 231-237.

15. Zhu X, Yang Z, Cui B, Zhang D, Thein B (2016) Self-medication practices with antibiotics among Chinese university students. Public Health 130: 78-83.

16. Sheethal MP, Shanthi M, Vishma B (2014) A cross-sectional study on self medication among nursing students in Mandya. IJHSR 4: 79-83.

17. Bala R, Singh H, Kaur K, Kohli K (2013) Knowledge and attitude towards antimicrobial self-medication usage: A cross sectional study among medical and nursing students. Int J Basic Clin Pharmacol 2: 428-432.

18. Phiney TP, Aditya S, Sumi R, Ashok K (2012) Assessment of self medication practices among undergraduate medical and paramedical students: A case of rural medical school of Tamil Nadu, India. WJ Pharm Pharm Sci 4: 1587-1604.

19. Allison W, Kimberley C (2014) Self-medication practices among undergraduate nursing and midwifery students in Australia: A crosssectional study. Contemp Nurse 52: 410-420.

20. Souza LA, Da Silva CD, Ferraz GC, Sousa FA, Pereira LV (2011) The prevalence and characterization of self-medication for obtaining pain relief among undergraduate nursing students. Rev Lat Am Enfermagem 19: 245-251.

21. Barros, Aline Reis Rocha, Griep, Rosane Harter, Rotenberg Lúcia (2009) Self-medication among nursing workers from public hospitals. Revista Latino-Americana de Enfermagem 17: 1015-1022.

22. Adnan M, Karim S, Khan S, Sabir A, Lafi Al-Banagi AR, et al. (2015) Evaluation of self-medication practices and awareness among students in Al Qassim region of Saudi Arabia. Clin Pharmacol Biopharm 4: 133.

23. Eric S Donkor, Patience B Tetteh-Quarcoo, Patrick Nartey, Isaac O Agyeman (2012) Self-medication practices with antibiotics among tertiary level students in Accra, Ghana: A cross-sectional study. Int J Environ Res Public Health 9: 3519-3529.

24. Fadare JO, Tamuno I (2011) Antibiotic self-medication among university medical undergraduates in Northern Nigeria. J Public Health Epidemiol 3: 217-220.

25. Olayemi OJ, Olayinka BO, Musa AI (2010) Evaluation of antibiotic selfmedication pattern amongst undergraduate students of Ahmadu Bello University (Main Campus), Zaria. Res J App Sci Eng Technol 2: 35-38. 
Citation: Khanam P, Haj-Ali D (2017) Assessment of the Knowledge and Self-Medication Behaviours towards Antibiotics among Nursing Students at King Saud Bin Abdulaziz University for Health Sciences, Al Ahsa. J Nurs Care 6: 431. doi:10.4172/2167-1168.1000431

Page 6 of 6

26. Aljadhey H, Assiri GA, Mansour MA, Al-Aqeel S, et al. (2015) Selfmedication in Central Saudi Arabia, community pharmacy consumers' perspectives. Saudi Med J 36: 328-334.

27. Divya G, Sanjay G (2013) Self-medication patterns among nursing students in North India. IOSR J Dent Med Sci (IOSR-JDMS) 11: 14-17.

28. Ali AS, Ahmed J, Ali AS, Sonekhi GB, Fayyaz N, et al. (2016) Practices of self-medication with antibiotics among nursing students of Institute of Nursing, Dow University of Health Sciences, Karachi, Pakistan. J Pak Med Assoc 66: 235-237.
29. Manisha CG, Vaishali RM (2013) Assessment of self-medication practices among staff nurses. Indian J Sci Res 4: 81-84.

30. Mayadah S, Ghadeer S, Rula MD, Mayyada W, Luna Z, et al. (2012) Knowledge, attitudes and behavior regarding antibiotics use and misuse among adults in the community of Jordan. A pilot study. Saudi Pharm J 20: $125-133$.

31. Rebecca RC, Jiayang S, Robin LP Jump A (2016) Survey and analysis of the American public's perceptions and knowledge about antibiotic resistance. Open Forum Infect Dis 3: 112. 